\title{
Cell wall characterization of new Monastrell hybrid descendants and their phenolic wine composition
}

\author{
Juan Daniel Moreno-Olivares ${ }^{1}$ [D · Diego Fernando Paladines-Quezada ${ }^{1} \cdot$ María José Giménez-Bañón $^{1}$. \\ Ana Cebrían-Pérez ${ }^{1}$ · José Ignacio Férnandez-Férnandez ${ }^{1}$. José Cayetano Gómez-Martínez ${ }^{1}$. \\ Juan Antonio Bleda-Sánchez ${ }^{1}$ Rocío Gil-Muñoz ${ }^{1}$
}

Received: 3 September 2021 / Revised: 14 January 2022 / Accepted: 15 January 2022 / Published online: 24 January 2022 (c) The Author(s) 2022

\begin{abstract}
Monastrell grape variety is grown for the elaboration of quality red wines, but climate change has meant the study of new grape varieties from Monastrell, to adapt to the new edaphoclimatic scenario in hot climates. Three new varieties have recently been registered from Monastrell (M) from directed crosses with others such as Cabernet Sauvignon (C) and Syrah (S). These new varieties are MC80 known as Calnegre, MC98 Gebas, and MS10 Myrtia. In this work, cell wall characterization of these new varieties has been carried out. Results from three seasons showed high significant differences in the concentration of carbohydrates present in the Monastrell and MC80 cell walls. As for lignin concentration, MS10 was highlighted. However, the concentration of phenolic compounds and proteins was different as regards each variety and season studied. To find some correlation between the characterization of the walls and extractability of different compounds in the wine, the phenolic composition of these wines from these varieties was analysed following alcoholic fermentation. All crosses presented a higher concentration of total polyphenols (IPT) and total anthocyanins (AT) in addition to color intensity (IC), highlighting the high significant differences found in MS10.
\end{abstract}

Keywords Crosses $\cdot$ Hybrids $\cdot$ Phenols $\cdot$ Vitis vinifera $\cdot$ Cell wall $\cdot$ Climate change

\begin{tabular}{ll}
\multicolumn{2}{l}{ Abbreviations } \\
AU & Uronic acids \\
TP & Total phenols of cell wall \\
IC & Color intensity \\
IPT & Total polyphenol index in wines \\
CG & Cellulosic glucose \\
AT & Anthocyanins
\end{tabular}

\section{Introduction}

Climate change is a real current problem bringing unfavourable consequences in multiple areas; one of the most noticeable effects is that the surface mean temperature is continuously rising [1]. The agricultural sector has been very affected by temperature increase and viticulture is one agricultural sector of major economic importance in

Juan Daniel Moreno-Olivares

juand.moreno5@carm.es

1 Instituto Murciano de Investigación Y Desarrollo Agrario Y Alimentario, C/ Mayor s/n La Alberca, 30150 Murcia, Spain
Mediterranean climate zones [2] and numerous areas of the world. The shift in climate and the resulting changes to weather patterns may cause shifts in grape chemistry and the resulting wine quality. With the warming of the climate, not only is the phenological period of grapes advanced, but the components of the ripening period are also affected [3]. In many producing areas, an increasing trend of sugar is detected, which increases the potential alcohol content of wine, while acidity is significantly decreased [3] and this is one of the main reasons why the Monastrell grape variety, grown mainly in the south east of Spain, is beginning to suffer the consequences of climate change. These reasons lead to an unbalanced in wines, with differences between acidity, sugar, and alcohol, as well as deterioration in the organoleptic characteristics of wines resulting with less antioxidant capacity. Therefore, it is interesting to search for new varieties that can withstand these climatic changes. It is a fact that Monastrell is a grape variety which needs a very good ripening of the grape, to obtain a good concentration of phenolic compounds and, therefore, get a good color, with the disadvantage that more alcoholic wines are elaborated. Some options can be employed such as crossbreeding or 
bud mutation as the most common ways of developing new wine grape cultivars [4]. Our research centre (IMIDA) has been developing breeding programs since the 90s [5-7] to select new varieties adapted to the current edaphoclimatic conditions and with high phenolic content. Directed crosses between Monastrell and other improvers such as Cabernet or Syrah are the tool used. Cabernet Sauvignon and Syrah are two varieties with higher concentrations in polyphenols than Monastrell due to mainly its easy of extracting the compounds. The crosses obtained from these varieties through the emasculation process have given rise to new varieties with high polyphenolic concentrations. Its adaptation to climate change is due to the fact that at harvest time, these new varieties reach concentrations much higher than Monastrell, even being harvested in advance and even with temperatures greater than $30^{\circ}$ (Data shown in Table 1 of Supplementary Material). With the growing of these new varieties from Monastrell, the time of harvest is being advanced about 21 days with respect to Monastrell [8], obtaining high concentrations of phenolic compounds despite the high temperatures in the area $\left(35-40{ }^{\circ} \mathrm{C}\right)$. Through these years, ten red grape varieties and three white grapes have been selected according to our requirements; three of which (Myrtia, Calnegre, and Gebas) are in the registration phase ending 2021. Previous published studies have shown results on phenolic composition, profile, and content in berries from other Monastrell hybrids. Hernández-Jiménez et al. [9] explored the characteristics of anthocyanins and flavonols in crosses from Monastrell $\times$ Cabernet Sauvignon, Monastrell $\times$ Syrah and Monastrell x Barbera; Gómez-Plaza et al. [5] evaluated the distribution of the anthocyanin profile in 143 plants arising from crosses between Monastrell $\times$ Cabernet; MorenoOlivares et al. [7] characterized the volatile composition of white crosses from Monastrell and Apolinar-Valiente et al. [10] characterized the cell wall of ten hybrids from Monastrell $\times$ Cabernet Sauvignon. In addition, although the phenolic composition in grape skins and mechanisms of their inheritance have been widely studied, there are not so many studies of its cell wall structure; so, it is necessary to acquire information on properties related to the grape and wine quality of these three new varieties that will soon be registered. The composition and structure of cell walls from grape skins in these new genotypes has not been previously reported. Grape skin cell wall plays an important role in oenology, acting as a protective barrier for extraction of color and aroma components during winemaking [10]. As is well known, grape berries are composed of tissues and cells which in turn are surrounded by polysaccharide-rich cell walls. Besides, grape cell walls need to be deconstructed (broken down) to release components such as metabolites (e.g., sugars, acids, volatiles, pigments) and polymers (e.g., pectins, proteins, polyphenols such as tannins) into the fermenting must (i.e., grape juice) for wine production [11]. Depending on how the cell wall of the grapes breaks, a quality wine will be obtained, affecting factors such as the yield of the juice, its quality, and the typicality of the crop. Once the compounds of interest have been extracted and the wines made, it is essential to determine and quantify the concentration of these types of compounds in the wines obtained from the Monastrell crosses, to verify the transfer of phenolic compounds from the improving varieties to Monastrell. Furthermore, it is widely accepted that wine phenolic compounds are quality indicators, especially in red wines [12]; thus, it is fundamental to its quantification from the enological point of view. Due to the above, the aim of this research was to evaluate the skin cell wall composition, skin visualization by transmission optical microscopy, to study the phenolic composition of wines as well as try to understand the ability to release polyphenolic compounds in Monastrell and new wine varieties. All of this was done with a focus on showing the improvement in terms of the Monastrell variety.

\section{Materials and methods}

\section{Reagents and standards}

Pure water was obtained from a Mili-Q purification system (Millipore, US). Merck (Darmstadt, Germany). Pure acetone, ethanol $96 \%$, sodium hydroxide $1 \mathrm{~N}$, sulphuric acid 98\%, and ammonium sulphate were purchased from Panreac (Barcelona, Spain). Enzymatic analysis kit from $R$-biopharm (Darmstadt, Germany) was used in glucose determination. Pure galacturonic acid, gallic acid, 3,5-dimethylphenol, Bradford reagent, Phenol, Folin-Ciocalteau phenol, and methylcellulose reagent were purchased from Sigma-Aldrich (St. Louis, USA) and bovine serum albumin (BSA) from J.T. Baker (Deventer, The Netherlands); Glacial acetic acid (99\%) from Fluka (Buchs, Switzerland).

\section{Vegetal material}

The experiment was performed in three consecutive seasons (2017-2019) using Monastrell as parental variety and three new varieties Calnegre or MC80 (Monastrell $\times$ Cabernet), Gebas or MC98 (Monastrell $\times$ Cabernet), and Myrtia or MS10 (Monastrell $\times$ Syrah) in vineyards (Vitis vinífera L. c.v.) red wine grapevines grafted onto R110 rootstock, located in an experimental field in Bullas (Murcia, southeast Spain), latitude 38.11 and longitude -1.68 where the soil is characterized as loamy sand. Twenty plants by variety are trained to a three-vine vertical trellis system and withinrow spacing of $3 \times 1.25 \mathrm{~m}$. 


\section{Physicochemical characterization of grapes}

Several controls were performed during the ripening process and when vines reached optimum phenolic maturity were harvested manually. Phenolic maturity was performed by monitoring the total anthocyanin concentration. When they reach a maximum and begin to decline, it was time to taste the skin of the grape (differentiate between acidity and vegetable notes or more neutral and fruity character). Next, the seeds were observed, and when more than $90 \%$ brown was observed, the varieties were harvested. The yield ( $\mathrm{kg} / \mathrm{vine})$ was measured. At harvest, ${ }^{\circ}$ Brix was measured in each sample to check the ripening stage using a Refractometer Atago RX-5000X (Atago CO, Ltd, Tokyo, Japan). Total acidity $\left(\mathrm{g} \mathrm{L}^{-1}\right)$ and $\mathrm{pH}$ levels were measured using a Metrohm (MetrohmAG, Herisau, Switzerland) with a glass electrode (6.0233.100; Metrohm, Herisau, Switzerland). The analysis were in triplicate.

\section{Vinifications}

Grapes were transported to the winery located in Jumilla, where wines were elaborated in accordance with a traditional vinification protocol in $100 \mathrm{~L}$ steel tanks. Grapes were destemmed and crushed, and sulphurous was added $(50 \mathrm{mg} \mathrm{SO} / \mathrm{kg}$ ). Commercial yeasts (Zymaflore FX10 Sacharomyces cerevisiae) were used. Alcoholic fermentation (conducted at $25^{\circ} \mathrm{C}$ ) was controlled by monitoring the density and enzymatic determination of residual sugars (Cetlab 600, Microdom, Taverny, France; TDI chemical analyser, Tecnología Difusión Ibérica, SL, Barcelona, Spain), until a value of reducing sugars $<0.2 \mathrm{~g} \mathrm{~L}^{-1}$ and density $<1.0 \mathrm{~g} \mathrm{~mL}^{-1}$ was achieved. The skins were in contact with the must for 15 days. When alcoholic fermentation finished, wines were pressed at 1.5 bar in a $75 \mathrm{~L}$ tank membrane press. Then, 2 days after pressing a racking were carried out to eliminate reduction odours due to lees, and 4 days after this, another racking was made to remove more lees. Finally, wines underwent malolactic fermentation at $20^{\circ}$, and were racked and placed in a bag in box (for better conservation and to prevent gaps with oxygen in the tanks). Samples were analysed in triplicate at the end of alcoholic fermentation.

\section{Isolation of cell wall material (CWM)}

Cell wall material was isolated using the procedure described by Paladines-Quezada et al. [13]. Triplicate grape samples $(3 \times 100 \mathrm{~g})$ were frozen at $-20^{\circ} \mathrm{C}$ and peeled with a scalpel. Then, the skins were stored at $-20{ }^{\circ} \mathrm{C}$ until cell wall material isolation. Five grams of grape skin was suspended in $50 \mathrm{ml}$ of boiling water for $5 \mathrm{~min}$ to inactivate enzymes. The final volume was centrifuged, and then, the supernatant was removed. The sample was mixed several times with $70 \%$ ethanol and extracted for $30 \mathrm{~min}$ at $40{ }^{\circ} \mathrm{C}$ to eliminate sugars. After each $30 \mathrm{~min}$ wash, the process is the same, centrifuged and removed the supernatant to later add alcohol and do more washes. A sample from the liquid phase was taken for soluble sugar analysis to check if sugars had been eliminated [14]. Alcohol insoluble solids (AIS) were then rinsed twice with $96 \%$ ethanol and once with acetone (always centrifuging and removing the supernatant after each wash). Finally, samples were dried overnight under an air stream at $20^{\circ} \mathrm{C}$.

\section{Analysis of grape skin cell wall composition}

The cell wall composition was analysed in quadruplicate according to Apolinar-Valiente et al. [15]. The following analysis was performed: uronic acids, proteins, total phenolic compounds, total glucose, cellulosic glucose, noncellulosic glucose, and lignin. Uronic acids were determined in the sulphuric acid hydroxylate by the colorimetric 3.5-dimethylphenol assay after pre-treating cell walls $\left(30^{\circ} \mathrm{C}\right.$, $1 \mathrm{~h}$ ) with aqueous $72 \%$ sulphuric acid, followed by hydrolysis with $1 \mathrm{M}$ sulphuric acid $\left(100{ }^{\circ} \mathrm{C}, 3 \mathrm{~h}\right)$; according to Scott method [16], pure galacturonic acid was used as standard. Proteins and total phenolic compound were determined after extraction with $\mathrm{NaOH} 1 \mathrm{M}\left(100{ }^{\circ} \mathrm{C}, 10 \mathrm{~min}\right)$ by the colorimetric Coomassie Brilliant Blue assay and the colorimetric Folin-Ciocalteau reagent assay by Bradford method [17]. Bovine serum albumin (BSA) fraction $\mathrm{V}$ and pure gallic acid were used as standards, respectively. Total glucose was determined using a kit for glucose enzymatic analysis from TDI with a Miura 200 (Rome, Italy) after pre-treatment $\left(30{ }^{\circ} \mathrm{C}, 1 \mathrm{~h}\right.$ ) with aqueous $72 \%$ sulfuric acid, followed by hydrolysis using sulfuric acid $1 \mathrm{M}\left(100{ }^{\circ} \mathrm{C}, 3 \mathrm{~h}\right)$ to determine non-cellulosic glucose following Castro-López methodology [18], and also, cellulosic glucose was obtained by difference between the total glucose and non-cellulosic glucose content. Finally, Klason lignin was determined gravimetrically following sulphuric acid hydrolysis [19]. Lignin content was expressed as $\mathrm{mg} \mathrm{g}^{-1}$ of cell wall.

\section{Spectrophotometric parameters in wines}

Total polyphenols (IPT), total anthocyanins (TA), color intensity (CI), and total tannins were analysed in wine samples just at the end of alcoholic fermentation and analysed on a Shimadzu UV/visible spectrophotometer 1600PC (Shimadzu, Duisburg, Germany) in triplicate. IPT were analysed measuring absorbance at $280 \mathrm{~nm}$ according to RibéreauGayon et al. [20], TA were measured by a method proposed by Ho et al. [21], CI was calculated as the sum of absorbance at 620,520 , and $420 \mathrm{~nm}$ in undiluted wine [22], and 
tannins were measured using the method of precipitation of methylcellulose [23].

\section{Transmission optical microscopy}

Skin samples from Monastrell, MS10, MC80, and MC98 were prepared for visualization by transmission optical microscopy. The methodology used was the same as Amrani Joutei, Glories, and Mercier [24] with the modifications of Apolinar-Valiente et al. [15]. Small pieces of skin $\left(1 \mathrm{~mm}^{3}\right)$ were cut from the vascular tissue close to the pericarp and fixed in $2.5 \%(\mathrm{v} / \mathrm{v})$ glutaraldehyde in $0.1 \mathrm{M}$ phosphate buffer, $\mathrm{pH} 7.2$ at $4{ }^{\circ} \mathrm{C}$ for $2 \mathrm{~h}$. Samples were later rinsed several times in the same buffer, post-fixed at $4{ }^{\circ} \mathrm{C}$ for $2 \mathrm{~h}$ in an osmium tetroxide solution, and then repeatedly rinsed in the buffer. After dehydration through an ethanol gradient series (30\%, 50\%, 70\%, and 90\%) with copper sulphate and propylene oxide solution (15 min each), tissues were infiltrated with Spurr resin. Ultra-thin sections were stained with toluidine blue and viewed using optical microscopy.

\section{Statistical analysis}

Significant differences among grapes and wines were assessed by variance analysis for each variable. A least significant difference (LSD) test was used to separate the means $(p<0.05)$ in physicochemical analysis of grapes, in the study of the composition of cell wall skins (proteins, total phenols, lignin, cellulosic glucose, and uronic acids) and in phenolic composition and chromatic analysis (anthocyanins, color intensity, IPT, and tannins). Besides, a multivariate statistical analysis (discriminant analysis and heat map) were conducted using RStudio 3.6.2 (Boston, MA).
Furthermore, Pearson correlation coefficients of IPT, tannins, anthocyanins, color intensity, uronic acids, total phenols, lignin, proteins, and sugars data were calculated with the statistical package Statgraphics 18.

\section{Results and discussion}

\section{Physicochemical characteristics of grapes}

The physicochemical data of the progeny and Monastrell at moment of harvest in each year are shown in Table 1. As mentioned above, the cultivars studied were grown in the same plantation framework $(3 \times 1.25)$ with a density of 2666 vines/ha. As observed, grapes in 2017 and 2019 seasons were harvested earlier than in 2018 due to climatological conditions (Supplemental Table 1). As regards hybrids, MS10 was the variety harvested earlier in the 3 years studied; specifically the 11st of August 2017; The 30st of August 2018 and the 22st August 2019. Showing a difference of almost 20 days compared to the first year of study. Monastrell was the last variety harvested as it is a variety adapted to hot climates and therefore matures later than other varieties [6]. In general, the yield (kg/vine) obtained in 2019 was higher than in 2017 and 2018. Regarding hybrids, the highest yield ( $3.14 \mathrm{~kg} / \mathrm{vine}$ ) was obtained by MC98 in 2017, while MC80 was lowest with $1.36 \mathrm{~kg}$ per vine; in 2018, Monastrell had highest production (2.86 kg/vine), and MC80 the least with only $1.17 \mathrm{~kg} / \mathrm{vine}$. Finally, in 2019, these same varieties obtained maximum and minimum values (3.12 and $2.11 \mathrm{~kg}$ by vine respectively). According to Merloni et al. [25], wine grape yield and quality are largely dependent on climatic conditions, particularly during the growing season.
Table 1 Physicochemical characteristics of grapes at harvest

\begin{tabular}{llllllll}
\hline Year & Varieties & Harvest date & Grape weight $^{\mathrm{A}}$ & $\mathrm{kg} / \mathrm{vine}$ & ${ }^{\circ}$ Brix & $\begin{array}{l}\text { Total acidity } \\
\text { (g/L tartaric } \\
\mathrm{acid})\end{array}$ & $\mathrm{pH}$ \\
\hline 2017 & & & & & & & \\
& & & & & & & \\
& MON & $26 / 09 / 2017$ & 174.11 & 1.93 & $23.75 \mathrm{~b}^{\mathrm{B}} \pm 0.01$ & $3.30 \mathrm{~d} \pm 0.02$ & $3.90 \mathrm{a} \pm 0.05$ \\
& MC80 & $04 / 09 / 2017$ & 110.79 & 1.36 & $22.24 \mathrm{~d} \pm 0.01$ & $4.50 \mathrm{c} \pm 0.07$ & $3.60 \mathrm{~b} \pm 0.01$ \\
& MC98 & $06 / 09 / 2017$ & 134.57 & 3.14 & $23.82 \mathrm{a} \pm 0.01$ & $4.90 \mathrm{~b} \pm 0.10$ & $3.91 \mathrm{a} \pm 0.01$ \\
& MS10 & $11 / 08 / 2017$ & 117.28 & 2.33 & $22.36 \mathrm{c} \pm 0.01$ & $6.00 \mathrm{a} \pm 0.01$ & $3.60 \mathrm{~b} \pm 0.00$ \\
2018 & MON & $24 / 09 / 2018$ & 131.77 & 2.86 & $23.50 \mathrm{~d} \pm 0.01$ & $3.01 \mathrm{c} \pm 0.01$ & $3.82 \mathrm{~b} \pm 0.01$ \\
& MC80 & $13 / 09 / 2018$ & 124.65 & 1.17 & $23.70 \mathrm{c} \pm 0.01$ & $3.81 \mathrm{~b} \pm 0.01$ & $3.61 \mathrm{c} \pm 0.01$ \\
& MC98 & $12 / 09 / 2018$ & 141.71 & 1.73 & $24.30 \mathrm{~b} \pm 0.00$ & $3.10 \mathrm{c} \pm 0.01$ & $3.94 \mathrm{a} \pm 0.01$ \\
& MS10 & $30 / 08 / 2018$ & 113.66 & 2.00 & $25.63 \mathrm{a} \pm 0.02$ & $3.92 \mathrm{a} \pm 0.02$ & $3.11 \mathrm{c} \pm 0.01$ \\
& MON & $25 / 09 / 2019$ & 151.00 & 3.12 & $23.10 \mathrm{~b} \pm 0.01$ & $3.71 \mathrm{~d} \pm 0.01$ & $3.82 \mathrm{a} \pm 0.01$ \\
& MC80 & $09 / 09 / 2019$ & 110.31 & 2.11 & $21.00 \mathrm{c} \pm 0.07$ & $3.82 \mathrm{c} \pm 0.01$ & $3.61 \mathrm{~d} \pm 0.01$ \\
& MC98 & $04 / 09 / 2019$ & 105.14 & 2.52 & $20.50 \mathrm{~d} \pm 0.07$ & $3.82 \mathrm{~b} \pm 0.01$ & $3.73 \mathrm{~b} \pm 0.01$ \\
& MS10 & $22 / 08 / 2019$ & 97.09 & 2.54 & $23.50 \mathrm{a} \pm 0.14$ & $4.50 \mathrm{a} \pm 0.00$ & $3.62 \mathrm{c} \pm 0.01$ \\
\hline
\end{tabular}

${ }^{\mathrm{A}}$ Grape weight expressed as the weight (g) of 100 berries

${ }^{\mathrm{B}}$ Different letters within the same column represent significant differences according to an LSD test $(p>0.05)$. The significant differences were determined per year and between varieties 
In our study, climatic conditions followed different trends in the three seasons studied (Supplemental Table 1). For instance, 2019 was less sunny during the veraison stage with slightly milder temperatures than the other years; however, 2018 was much rainier compared to the other 2 years, highlighting the importance that grapevines are highly sensitive to climatic conditions [26]. As for berry size, Monastrell was usually the largest, obtaining values ranged $1.74 \mathrm{~g}$ in 2017 and $1.51 \mathrm{~g}$ in 2019, while MC98 had the highest weight in 2018 with $1.41 \mathrm{~g}$. Having a larger grape size could be the fact that having a higher proportion of pulp could result in a dilution in concentration of compounds of interest. As for sugar content at time of harvest, MC98 showed the highest ${ }^{\circ}$ Brix in 2017, while MS10 was highest in 2018 and 2019. It should be noted that the time of harvest in 2018 was later than other years and therefore with ${ }^{\circ}$ Brix higher in all the studied varieties. However, Monastrell had an average of 23 ${ }^{\circ}$ Brix during the 3 years. This variation in harvest time could have an influence on degradation of cell walls and thus the release of quality parameters during winemaking [11]. Total acidity in hot climates is usually lower compared to cold ones due to climate change in the Mediterranean area [6]. As seen in Table 1, in general, the new varieties did not reach high acidities; however, MS10 showed the highest values in the 3 years studied and specifically highlighted in 2017 with a value of $6.0 \mathrm{~g} \mathrm{~L}^{-1}$. By contrast, Monastrell presented the lowest values for this parameter during the three seasons. Evidently, the opposite occurred with $\mathrm{pH}$; this parameter obtained high values in Monastrell grapes, while lowest values were found in MS10. This is due to the fact that when a variety is harvested earlier, it provides better results in terms of acidity. Climatic conditions are perhaps the main factor explaining year-to-year differences [27].

\section{Cell wall characterization of grapes}

Table 2 shows data on the isolation of the cell wall from the different varieties studied. As seen, the amount of isolated cell wall material was different among varieties and years of study. The percentage skin values ranged between 6 and 13\% in the 3 years of study, and these results are in accordance with that found by Ortega-Regules [28] in some varieties such as Monastrell (10.8\%) or Syrah (11.9\%). By contrast, Apolinar-Valiente et al. [10] found that the percentage of skin in Monastrell hybrids comprised between 13 and $21 \%$. Our results showed that MC80 was the variety with highest percentage of skin in the 3 years of study with a mean value of $10.39 \%$, which is an advantage from the enological point of view, since the grape skins are the major source of color and aroma compounds [29]. On the contrary, MS10 obtained the lowest value in 2017 with $7.52 \%$ and Monastrell in 2018 and 2019 with $7.41 \%$ and $6.06 \%$, respectively. However,
Table 2 Percentage of skin in grapes and grams of cell wall in the skins of Monastrell and new varieties

\begin{tabular}{lllll}
\hline & & \% skin in grape & $\begin{array}{l}\mathrm{mg}^{\mathrm{A}} \mathrm{CW} / \mathrm{g} \\
\text { Fresh skin }\end{array}$ & $p$ value $^{\mathrm{B}}$ \\
\hline 2017 & MON & $8.63 \mathrm{c}$ & $82.50 \mathrm{c}$ & $* * *$ \\
& MC80 & $13.03 \mathrm{a}$ & $85.50 \mathrm{~b}$ & $* * *$ \\
& MC98 & $9.17 \mathrm{~b}$ & $83.50 \mathrm{~b}$ & $* * *$ \\
& MS10 & $7.52 \mathrm{~d}$ & $106.50 \mathrm{a}$ & $* * *$ \\
2018 & MON & $7.41 \mathrm{c}$ & $114.50 \mathrm{a}$ & $* * *$ \\
& MC80 & $10.15 \mathrm{a}$ & $108.50 \mathrm{~b}$ & $* * *$ \\
& MC98 & $7.82 \mathrm{~b}$ & $102.00 \mathrm{~d}$ & $* * *$ \\
& MS10 & $7.86 \mathrm{~b}$ & $104.50 \mathrm{c}$ & $* * *$ \\
& MON & $6.06 \mathrm{~d}$ & $113.50 \mathrm{a}$ & $* * *$ \\
& MC80 & $8.11 \mathrm{a}$ & $80.60 \mathrm{~d}$ & $* * *$ \\
& MC98 & $6.87 \mathrm{~b}$ & $107.40 \mathrm{~b}$ & $* * *$ \\
& MS10 & $6.70 \mathrm{c}$ & $86.60 \mathrm{~d}$ & $* * *$ \\
\hline
\end{tabular}

${ }^{\mathrm{A}} \mathrm{CW}$ cell wall

${ }^{\mathrm{B}}$ Different letters within the same column represent significant differences according to an LSD test $(p>0.05)$. The significant differences were determined per year and between varieties

${ }^{\mathrm{B}}$ Statistically significant at: $* p \leq 0.05, * * p \leq 0.01$, and $* * * p \leq 0.001$, respectively. NS, not significant

the low percentage of skin in MS10, will not show a low content of compounds of interest, suggesting that despite its low percentage of skin, it will extract a large amount of polyphenolic compounds, may have inherited the ease of extraction, of the Syrah variety. Regarding the amount of cell wall obtained in each variety studied (Table 2), the results were different in the 3 years of study. MS10 obtained a higher amount of cell wall in 2017 (106.50 mg), while Monastrell obtained $8 \mathrm{mg}$ more, being the variety which reported the highest amount of cell wall in 2018 and 2019 (114.50-113.50 mg, respectively). Different authors have also quantified high amount of cell wall in fresh skin in the Monastrell variety [10, 13, 29] and stated that Monastrell cell wall compared with other varieties such as Cabernet Sauvignon, Merlot, Syrah, and some hybrids, generally is thicker. This could indicate that the extraction of compounds of interest during the winemaking process is hindered. These differences are perfectly showed in the microscopy photos illustrated in OrtegaRegules et al. [29].

\section{Analysis of cell wall composition}

The main groups of compounds analysed in the cell walls isolated from Monastrell and their crosses during the three seasons are shown in Table 3. These are proteins, total phenols, lignin, cellulosic glucose, and uronic acids. 
Table 3 The composition of the cell walls from grape skins of the grape varieties studied

\begin{tabular}{lllllll}
\hline & Year & MON & MC80 & MC98 & MS10 & $p$ value $^{\mathrm{B}}$ \\
\hline Proteins & 2017 & $47.1 \pm 1.9$ & $46.2 \pm 3.4$ & $43.1 \pm 0.3$ & $45.2 \pm 0.6$ & $\mathrm{~ns}$ \\
& 2018 & $42.3 \mathrm{~b}^{\mathrm{A}} \pm 1.5$ & $41.0 \mathrm{~b} \pm 0.1$ & $49.2 \mathrm{a} \pm 0.8$ & $49.3 \mathrm{a} \pm 3.2$ & $* * *$ \\
& 2019 & $40.1 \mathrm{a} \pm 5.2$ & $43.2 \mathrm{a} \pm 0.3$ & $42.3 \mathrm{a} \pm 3.0$ & $34.2 \mathrm{~b} \pm 1.3$ & $*$ \\
Total phenols $_{(\mathrm{cw})}$ & 2017 & $33.1 \mathrm{a} \pm 1.2$ & $31.2 \mathrm{~b} \pm 0.3$ & $24.1 \mathrm{c} \pm 1.2$ & $22.9 \mathrm{c} \pm 0.1$ & $* * *$ \\
& 2018 & $22.8 \mathrm{~b} \pm 1.1$ & $20.2 \mathrm{~b} \pm 0.6$ & $23.0 \mathrm{~b} \pm 2.9$ & $27.3 \mathrm{a} \pm 1.3$ & $* *$ \\
& 2019 & $18.2 \mathrm{~b} \pm 2.6$ & $17.8 \mathrm{~b} \pm 0.1$ & $26.2 \mathrm{a} \pm 1,3$ & $23.03 \mathrm{a} \pm 2.3$ & $* *$ \\
Lignin & 2017 & $521.2 \mathrm{c} \pm 9.3$ & $589.3 \mathrm{ab} \pm 14.7$ & $565.9 \mathrm{~b} \pm 8.9$ & $615.3 \mathrm{a} \pm 23.6$ & $* * *$ \\
& 2018 & $578.7 \mathrm{a} \pm 3.2$ & $510.3 \mathrm{~b} \pm 33.5$ & $512.6 \mathrm{~b} \pm 5.3$ & $570.5 \mathrm{a} \pm 237$ & $* *$ \\
Cellulosic glucose & 2017 & $132.1 \mathrm{a} \pm 2.6$ & $110.0 \mathrm{bc} \pm 5.0$ & $118.3 \mathrm{~b} \pm 3.9$ & $108.2 \mathrm{c} \pm 6.1$ & $* * *$ \\
& 2018 & $139.4 \mathrm{a} \pm 6.9$ & $121.7 \mathrm{~b} \pm 8.6$ & $122.7 \mathrm{~b} \pm 3.4$ & $110.2 \mathrm{~b} \pm 12.6$ & $*$ \\
& 2019 & $126.4 \pm 9.7$ & $137.7 \pm 6.8$ & $121.9 \pm 7.8$ & $124.3 \pm 7.9$ & $\mathrm{~ns}$ \\
Uronic acids & 2017 & $266.2 \mathrm{a} \pm 7.1$ & $224.3 \mathrm{~b} \pm 11.0$ & $253.3 \mathrm{a} \pm 3.6$ & $209.2 \mathrm{~b} \pm 19.2$ & $* *$ \\
& 2018 & $218.4 \mathrm{~b} \pm 6.9$ & $307.5 \mathrm{a} \pm 29.3$ & $292.5 \mathrm{a} \pm 6.0$ & $243.3 \mathrm{~b} \pm 13.7$ & $* * *$ \\
& 2019 & $242.1 \mathrm{~b} \pm 6.3$ & $287.7 \mathrm{a} \pm 16.2$ & $273.8 \mathrm{a} \pm 0.5$ & $243.5 \mathrm{~b} \pm 19.9$ & $* *$ \\
\hline
\end{tabular}

${ }^{\text {A }}$ Different letters in the same row indicate significant differences according to LSD test $(p<0.05)$. Proteins (expressed as mg of BSA equivalents $\mathrm{g}^{-1}$ of cell wall), total phenols ${ }_{(\mathrm{cw})}$ (expressed as $\mathrm{mg}^{-}$of gallic acid $\mathrm{g}^{-1}$ of cell wall), lignin (expressed as $\mathrm{mg} \mathrm{g}^{-1}$ of cell wall), cellulosic glucose (expressed as $\mathrm{mg} \mathrm{g}^{-1}$ of cell wall), and uronic acids (expressed as $\mathrm{mg}$ of galacturonic acid $\mathrm{g}^{-1}$ of cell wall)

${ }^{\mathrm{B}}$ Statistically significant at: ${ }^{*} p \leq 0.05, * * p \leq 0.01$, and $* * * p \leq 0.001$, respectively. NS, not significant

\section{Protein compounds}

Proteins in the cell wall have been described as structural constituents forming a fibrillary net, reinforcing the wall during berry expansion [30]. Furthermore, it has also been reported that an increase in structural proteins contributes to the strength necessary to maintain berry integrity [31]. Proteins may be indicative of the stiffness found in the cell walls of different genotypes studied and of its parent. In our study, no significant differences were found in protein content between Monastrell and its crosses in 2017 (Table 3). In addition, MC98 and MS10 presented higher concentrations with respect to its parental Monastrell in 2018. Finally, in 2019, MS10 hybrid obtained the lowest protein concentration. With respect to Monastrell, MC80 and MC98, all of them reached similar concentrations $(40-43 \mathrm{mg})$. It is reasonable to believe that the lower protein content in grape skins could represent a weaker structural rigidity, helping the degradation of cell wall material from these grape skins [10].

\section{Total phenolic compounds}

Ortega-Regules et al. (2006) [28] described that in the primary cell wall, we found mainly ferulic acid and $p$-coumaric acid as the main phenolic compounds, which are usually found esterifying arabinose and galactose from pectic polysaccharides. Besides, Schnitzler et al. (1992) [32] proposed that phenolic compounds of the cell wall could participate in resistance against fungal pathogens, due to the types of bond formed by ferulic acid (oxidative interbreeding), since it apparently has the function of limiting the extension of the cell wall. Table 3 presents the mean values of the total phenolic compounds content of cell wall isolated from the skin of Monastrell and its new varieties. In our study, differences were found among years and varieties as PaladinesQuezada et al. [13] who showed differences between years in the composition of phenolic compound in the cell walls from three varieties (Monastrell, Cabernet Sauvignon, and Merlot); therefore, in 2017, Monastrell was seen to be the variety with higher concentration of total phenols $(33.1 \mathrm{mg}$ gallic acid $\mathrm{g}^{-1}$ cell wall) and MS10 had least concentra-

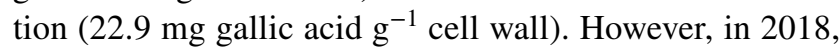
this hybrid, (MS10) presented the highest concentration (27.3 $\mathrm{mg}$ gallic acid $\mathrm{g}^{-1}$ cell wall) together with MC98

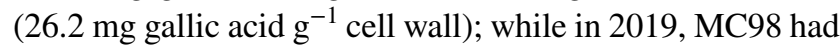
$26.2 \mathrm{mg}$ gallic acid $\mathrm{g}^{-1}$ and MS10 a value of $23.03 \mathrm{mg}$ gallic acid $\mathrm{g}^{-1}$ cell wall, respectively. The least concentration during the last season was obtained by MC 80 hybrid. ApolinarValiente et al. [10] reported that six out of ten Monastrell hybrids had significantly higher total phenolic compound values than Monastrell in a study of their cell walls.

\section{Lignin}

Lignin is a complex biopolymer primarily present in plant secondary cell wall, and is embedded in the cell walls of the plant vascular bundle, together with pectins, hemicelluloses, cellulose, and structural proteins [33]. Lignin composition is not strictly controlled but strongly depends on the relative abundance of the precursors delivered to the lignifying 
zone [34]. The lignin content showed differences among Monastrell and its hybrids depending on year. In 2017, MS10 (615.3 $\mathrm{mg} \mathrm{g}^{-1}$ cell wall) presented the highest values and Monastrell the lowest $\left(521.2 \mathrm{mg} \mathrm{g}^{-1}\right.$ cell wall). On the contrary, although MS10 continued to obtain the highest values during the 2 successive years; Monastrell also obtained highest values. In addition, lignin has been associated with mechanical support, sap conduction, and defence mechanisms [34].

\section{Carbohydrate composition (cellulosic glucose, uronic acids)}

\section{Cellulosic glucose}

It is fairly well accepted that cellulosic glucose and uronic acids represent the highest percentage of sugars in the cell walls of skin [35]. Our results showed that cellulosic glucose and uronic acids, together with lignin were the major grape cell wall components in our varieties. As observed, Monastrell showed the highest values of cellulosic glucose in 2017 and 2018 (132.1 and $139.4 \mathrm{mg} \mathrm{g}^{-1}$ of cell wall, respectively), while MC80 had highest content in cellulosic glucose in 2019 , reaching a value of $137.7 \mathrm{mg} \mathrm{g}^{-1}$ of cell wall. MS 10 also obtained the least values in 2017 and 2018 and MC98 in 2019. Differences in amount of cellulose have been observed in other studies; thus, Apolinar-Valiente et al. [10] reported differences among, Syrah, Cabernet Sauvignon and Monastrell varieties; or among Monastrell and ten intraspecific hybrids from Monastrell [10]. Cellulosic glucose quantities have been correlated with firmness [36]. Therefore, the high quantity of cellulosic glucose in cell walls from Monastrell during the first 2 years of study and hybrid MC 80 in the last year could hinder degradation and therefore the extraction of phenolic compounds from the skin during winemaking. Paladines-Quezada et al. [13] also found higher cellulose content in Monastrell cell walls compared to other varieties such as Cabernet Sauvignon and Merlot. By contrast, hybrids MS10 and MC98 would suggest a less rigid cell wall structure, facilitating the extraction of compounds of interest during their elaboration process.

\section{Uronic acids}

With respect to concentrations found in uronic acids, our results showed different trends in the 3 years studied. Monastrell had the highest value together with MC98 in 2017 and MS10 and MC80 the lowest. In 2018 and 2019, the highest uronic acid content was found in MC80 and the least in Monastrell. These results may suggest that differences found between the different studied varieties may be due to the genetics of each variety; however, a large factor indicates that within each variety, berry texture traits are vintage dependent, and skin hardness parameters in particular are related to seasonal climatic indices [6]. As mentioned above, the maturity of the grape is also a very important factor that can influence the greater or lesser concentration of these compounds. Therefore, it is evident that the carbohydrate composition of cell wall material isolated from the Monastrell and its progeny is different and hence could confer distinct structural characteristics to each [37].

\section{Optical microscopy}

The pericarp consists of three anatomically distinct tissues exocarp, mesocarp, and endocarp [38]. Images from the exocarp of skin samples from the three hybrids and its parental were performed by transmission optical microscopy in the last season (Fig. 1). A high thickness of cell walls can be observed in Monastrell and MC80 grape skin reinforcing our analytical data concerning total of cellulosic glucose (Table 3). Apolinar-Valiente et al. [10] also found this agreement in a Monastrell hybrid. With respect to Monastrell, Ortega-Regules et al. [29] and Apolinar-Valiente et al. [10] observed that Monastrell grape skin had thicker cell walls compared to other cultivars such as Cabernet Sauvignon. These authors deduced that Monastrell grapes seem to be genetically characterized by a more rigid cell wall structure in comparison to other varieties. The clearly thinner cell walls were observed in MS10 and MC98, and this could corroborate our chemical results showed in Table 3, since these varieties scarcely show layers compared to the rest of studied cultivars. It is known that the number of layers in the skin grape berries and their size are cultivar-specific [39]. Therefore, it could be suggested that the structure of MS10 hybrid skin (three skin layers) would facilitate the extraction of phenolic compounds during winemaking.

\section{Chromatic parameters and phenolic composition in wines}

The chromatic parameters and phenolic composition of the wines analysed at the end of alcoholic fermentation are shown in Table 4 . The polyphenols are released when grape cells are physically disrupted (grape crushing) or are degraded during maceration but even with extended maceration only a fraction of the total polyphenols present in the grapes, will be extracted [11], and in addition, this extractability will be influenced by interaction with cell wall and red winemaking practices [40]. As observed in Table 4, high significant differences between Monastrell and the new wine varieties were found regarding anthocyanins, color intensity, total polyphenol index (IPT), and tannins; this being a constant trend during the 3 years of study. In general, these parameters were always higher in the new wine varieties compared to Monastrell wines. As for anthocyanin concentration, Monastrell wines obtained the lowest values 
Fig. 1 Optical microscopy images of exocarp of Monastrell and its progeny in 2019. The sections were stained with toluidine blue and show the epidermis and mesocarp
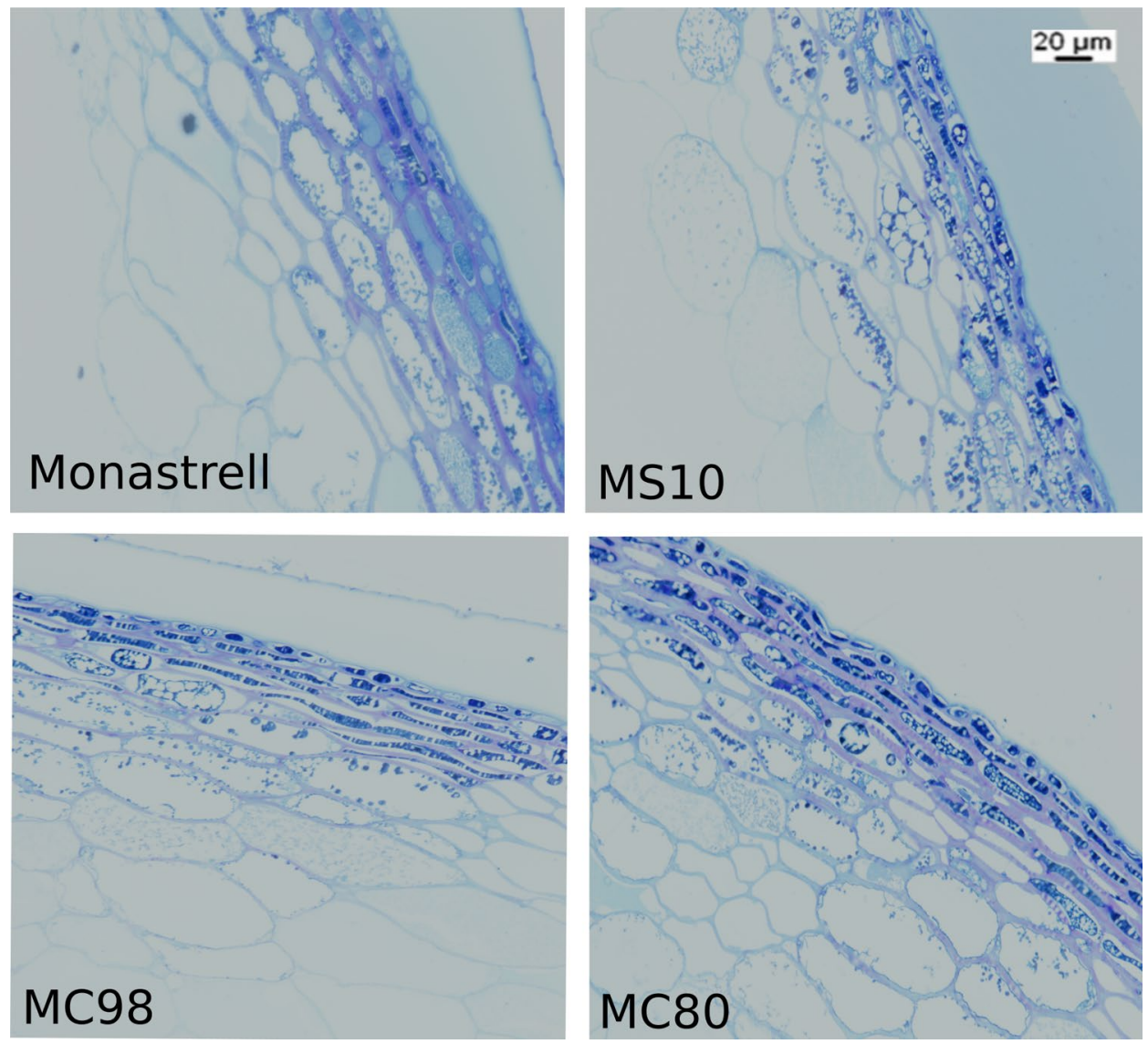

Table 4 Phenolic composition and wine chromatic characteristics of Monastrell and new varieties at the end of alcoholic fermentation

\begin{tabular}{lllllll}
\hline & Year & MON & MC80 & MC98 & MS10 & $p$ value $^{\mathrm{B}}$ \\
\hline Anthocyanins $\left(\mathrm{mg} \mathrm{L}^{-1}\right)$ & 2017 & $437 \mathrm{~d}^{\mathrm{A}} \pm 12$ & $1547 \mathrm{c} \pm 13$ & $1769 \mathrm{~b} \pm 76$ & $2225 \mathrm{a} \pm 13$ & $* * *$ \\
& 2018 & $633 \mathrm{~d} \pm 14$ & $1438 \mathrm{c} \pm 32$ & $1555 \mathrm{~b} \pm 19$ & $2038 \mathrm{a} \pm 40$ & $* * *$ \\
& 2019 & $565 \mathrm{~d} \pm 17$ & $1610 \mathrm{~b} \pm 8$ & $1256 \mathrm{c} \pm 23$ & $1949 \mathrm{a} \pm 17$ & $* * *$ \\
Color intensity & 2017 & $12.8 \mathrm{c} \pm 0.0$ & $46.6 \mathrm{~b} \pm 0.3$ & $45.6 \mathrm{~b} \pm 2.9$ & $63.6 \mathrm{a} \pm 0.4$ & $* * *$ \\
& 2018 & $16.1 \mathrm{~d} \pm 0.2$ & $42.1 \mathrm{~b} \pm 0.0$ & $39.3 \mathrm{c} \pm 0.2$ & $61.0 \mathrm{a} \pm 0.4$ & $* * *$ \\
& 2019 & $16,2 \mathrm{~d} \pm 0.2$ & $45.2 \mathrm{~b} \pm 0.1$ & $33.5 \mathrm{c} \pm 0.7$ & $59.1 \mathrm{a} \pm 0.1$ & $* * *$ \\
IPT & 2017 & $49.2 \mathrm{~d} \pm 0.4$ & $84.2 \mathrm{c} \pm 0.1$ & $93.0 \mathrm{~b} \pm 2.2$ & $110.1 \mathrm{a} \pm 1.5$ & $* * *$ \\
& 2018 & $42.1 \mathrm{~d} \pm 0.5$ & $92.1 \mathrm{~b} \pm 1.6$ & $78.1 \mathrm{c} \pm 0.7$ & $97.2 \mathrm{a} \pm 0.5$ & $* * *$ \\
Tannins $\left(\mathrm{mg} \mathrm{L}^{-1}\right)$ & 2019 & $40.3 \mathrm{~d} \pm 0.9$ & $81.1 \mathrm{~b} \pm 0.4$ & $71.0 \mathrm{c} \pm 1.0$ & $84.2 \mathrm{a} \pm 0.3$ & $* * *$ \\
& 2017 & $628 \mathrm{c} \pm 90$ & $2273 \mathrm{a} \pm 222$ & $2351 \mathrm{a} \pm 151$ & $1263 \mathrm{~b} \pm 223$ & $* * *$ \\
& 2018 & $838 \mathrm{~d} \pm 93$ & $1708 \mathrm{~b} \pm 116$ & $1799 \mathrm{a} \pm 147$ & $1549 \mathrm{c} \pm 41$ & $* * *$ \\
& 2019 & $688 \mathrm{~d} \pm 31$ & $1724 \mathrm{~b} \pm 137$ & $1800 \mathrm{a} \pm 77$ & $1166 \mathrm{c} \pm 135$ & $* * *$ \\
\hline
\end{tabular}

Color intensity corresponds to the sum of three absorbance units $(620,520$, and 420) with an optical path of $10 \mathrm{~mm}$. IPT Total polyphenol index in wines expressed as index with a dilution factor

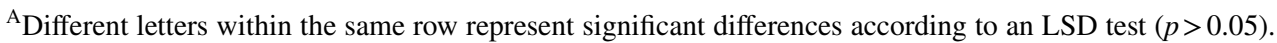
Significant differences were determined per year and between varieties

${ }^{\mathrm{B}}$ Statistically significant at: $* p \leq 0.05, * * p \leq 0.01$, and $* * * p \leq 0.001$, respectively. NS, not significant (average $557 \mathrm{mg} \mathrm{L}^{-1}$ ) and MS10 wines highest (average $2071 \mathrm{mg} \mathrm{L}^{-1}$ ) quadrupling its concentrations The remaining two hybrids also obtained much higher values (average 1532 and $1537 \mathrm{mg} \mathrm{L}^{-1}$ for MC80 and MC98, respectively) than Monastrell during the three seasons studied. Gil-Muñoz et al. [41] showed how wines made with Monastrell hybrids obtained a higher concentration in anthocyanins compared to Monastrell wines. The extraction in greater or lesser quantity 
of anthocyanins will depend on degradation by pectolytic enzymes of grape skins during ripening [9] not forgetting that this extraction will be quite difficult depending on how the cell wall of the grapes is structure. By contrast, other authors have demonstrated that knowing the quantities of anthocyanins in grape skins is not sufficient for estimating wine anthocyanin concentrations and this lack of correlation has been commonly attributed to the partial retention of these anthocyanins in skin cells due to the barrier effect of cell walls [42]. In addition to above mentioned, it was decided to carry out a correlation study with the different parameters studied for the shake of understanding which parameters could affect more to the release of the anthocyanins. If only the data of new varieties are used for the calculation, as can be noted in Fig. 2, what is facing us is a Pearson correlation graphic. Graphic brings evidence about the relations between the parameters (IPT, tannins, anthocyanins, color intensity, uronic acids, total phenols, lignin, proteins, and sugars) and this gives out information really important to us. It is well known that exists a high correlation between color intensity and anthocyanins, and this is perfectly shown in Fig. 2. $(r=0.96)$. The color of red wine is directly correlated with the content of anthocyanins, so it is therefore foreseeable that wines obtaining highest concentrations of these compounds are which show the highest color intensity values. As observed in Table 4, MS10 wines (average 61) obtained the highest results compared to Monastrell wines (average 15). With respect to the other varieties (MC80 and MC98), higher values were also obtained compared to wines from its parental variety (average 45 and 39, respectively). Furthermore, Fig. 2 provides some insights on the anthocyanin release. Not only was obtained a significant negative correlation between uronic acids and anthocyanins $(r=-0.70)$, but also was found a positive correlation between lignin and anthocyanins $(r=+0.69)$.

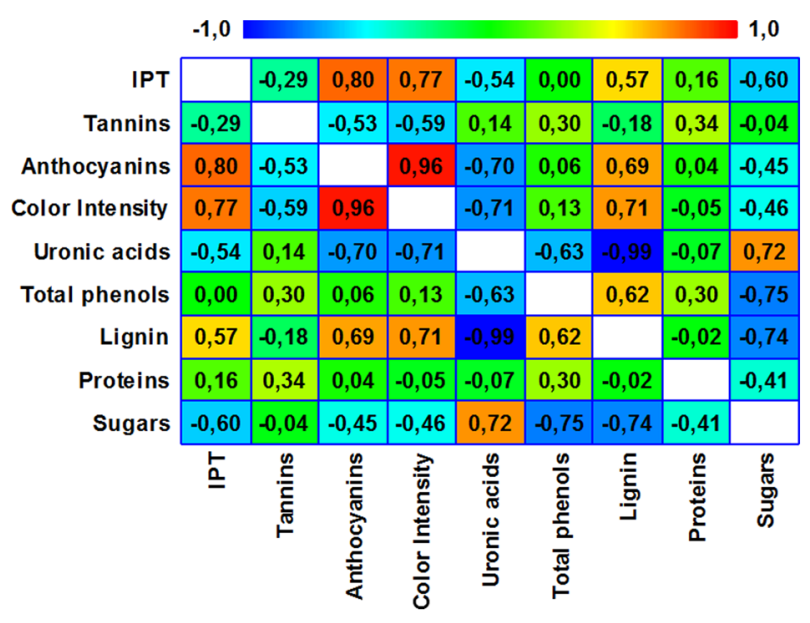

Fig.2 Pearson correlation coefficients
Besides, graphic shows a strong negative correlation among them (uronic acids and lignin) $(r=-0.99)$. This information could be really valuable in the characterization of these new varieties. This results suggest that a higher uronic acid concentration gives a lower release of anthocyanins, and it can be seen in Tables 3 and 4. Furthermore, in these tables which can be observed when lignin content is higher, the concentration of anthocyanins increases too. These results are contrary to found in Ortega-Regules et al. (2006) [43] or Hernández-Hierro et al. (2014) [9]. Yet, it is important to highlight the high anthocyanin concentration that these new varieties have compared to others varieties (Monastrell, Cabernet Sauvignon, Syrah, and Tempranillo), even achieving duplicate, triple, or quadruple the concentrations of these varieties. All things considered, it is suggested that the large number of anthocyanins that these new varieties have makes it possible to extract more of these compounds in wines. Definitely, not only uronic acids determine if the wines produced will have more or less anthocyanins, but also there are many features to consider. For instance, physical properties of grape skins like berry skin hardness, berry skin thickness, number of cell layers, cell wall thickness, and grape variety between others are linked to the anthocyanin extractability [9], and also how the compounds on the wall are organized. Regarding tannin concentrations in Table 4, in most cases, new wine varieties, again obtained a higher concentration compared to Monastrell wines. This trend continued during the 3 years, the highest concentration in MC98 wines (average $1983 \mathrm{mg} \mathrm{L}^{-1}$ ), the other hybrids (MC80 and MS10) also obtained wines with higher concentrations of tannins than Monastrell (1908 and $1306 \mathrm{mg} \mathrm{L}^{-1}$, respectively). These results could be explained by the fact that the presence of anthocyanins improves the extraction of tannins from both skin and seeds as these compounds compete with tannins for cell wall adsorption sites [42], and in addition, the differences in nature of skin-derived and seed-derived tannins can influence their affinities for cell wall material and their final extractability [44, 45]. Another factor influencing interaction between cell wall components and tannins is grape ripeness level; so, tannin-binding capacity increases as grape berries ripen [11]. Polyphenolic content is an important parameter determining some organoleptic and sensorial properties of wines. Results showed the same trend that in the other chromatic parameters measured Table 4, during the 3 years studied, wines with highest values of polyphenolic compounds was found in MS10, and wines with lowest values was found in the parental Monastrell. Some studies have also shown low values of these parameters in Monastrell wines [46, 47]. Other authors have also found links between cell wall sugar composition, grape ripeness levels and the corresponding of phenolic extractability [9, 48, 49], or correlation between extractability index and of anthocyanin extraction [28]. Therefore, one might think that the phenolic composition 


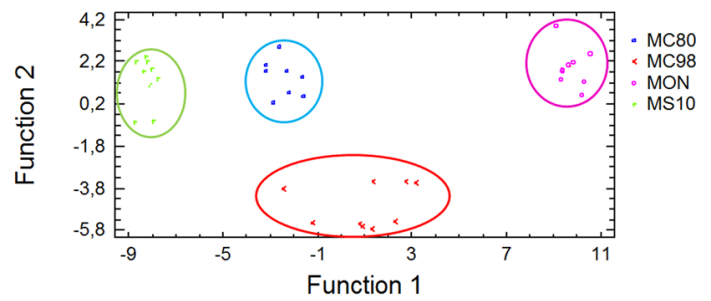

Fig. 3 Distribution of varieties in the coordinate system defined by discriminant functions

found in wines is more correlated with the characteristics of each variety inherited from its parents than a possible relationship between cell wall composition and extractability.

\section{Discriminant analysis}

A multivariate discriminant analysis was used to check whether the measured variables could distinguish between Monastrell and its hybrids. Nine predictor variables were entered (proteins, total phenols, lignin, cellulosic glucose, uronic acids, anthocyanins, tannins, color intensity, and total polyphenol index) and three discriminating functions with $p$ values less than 0.05 were statistically significant at $95 \%$ confidence level. These three discriminant functions allowed $100 \%$ of correct classification of samples according to variety Fig. 3. The relative percentage for function 1 was $84.44 \%$ and $14.51 \%$ for function 2 . Table 2 (supplementary material) shows the coefficients of functions used to discriminate among the different varieties. From the different magnitude of these coefficients, it can be determined how independent variables are used to discriminate among groups [28]. Variables with the highest discriminant power were anthocyanin, lignin, uronic acid content, and the color intensity parameter. As seen, the separation of the three new varieties was perfect with respect to Monastrell (Fig. 3). MS10 is located farther from Monastrell indicating greater differences regarding this variety. According to our previous results, MS10 could have a different cell wall, thinner than the rest of cultivars. The other two varieties (MC80 and MC98) are located in the figure in the middle of MS10 and Monastrell, which would indicate greater similarity with this parental.

\section{Heat map}

In each year of study, the diversity of Monastrell and new varieties with the principal variables was visualized by hierarchical clustering and a heat map (Fig. 4). Heat maps are ubiquitous in the genomic literature and are quite useful for visualizing measurements, a subset of rows representing all samples [7]. Each row depicts the main group for individual varieties. This heat map simultaneously enables visualizing clusters of samples and features. First, a hierarchical

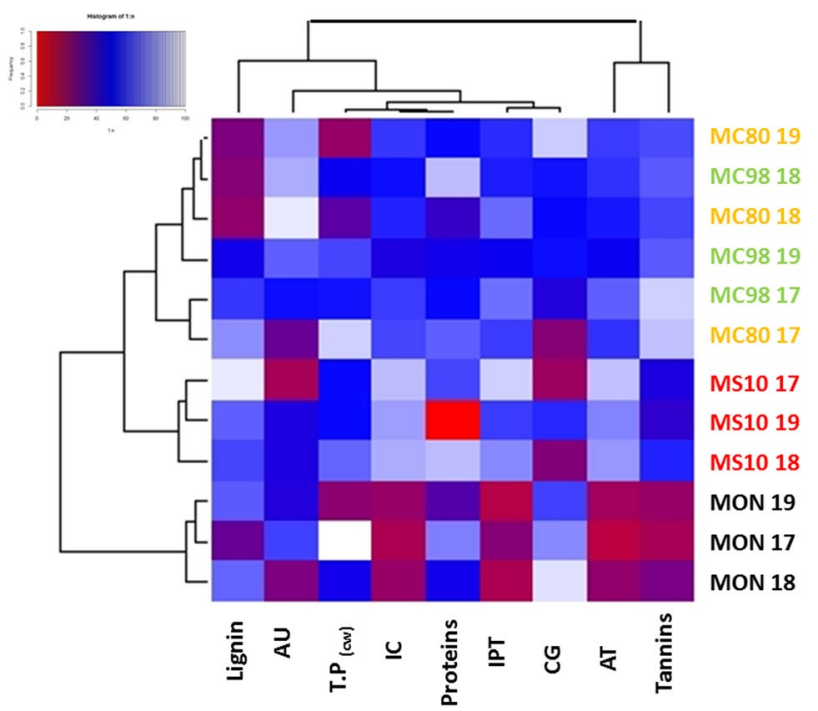

Fig. 4 Heat map correlations for the different variables according to a cluster analysis of Monastrell and the new varieties. In brief, white colors indicate positive correlation, red indicate negative correlations, and blue indicate intermediate correlations

clustering was carried out of both rows and columns of the data matrix. The columns/rows of the data matrix were reordered according to the hierarchical clustering result, placing similar observations close to each other. As a result, a color scheme was applied for visualization. Finally, visualizing the data matrix in this way can help to find variables which appear to be characteristic for each sample cluster. As seen on the left of Fig. 4, in the hierarchical clustering (the horizontal axis of the dendrogram which represents the distance or dissimilarity between clusters), three branches are observed. The first separates Monastrell in the 3 years of study from the rest of varieties. The other branch then groups the 3 years of study of MS10. Finally, in the last branch, a mix of varieties can be seen (MC80 and MC98) which could suggest certain similarity between them, and these results are confirmed with the optical microscopy images and discriminant analysis. As observed, the new varieties are separated from Monastrell, suggesting that these new varieties have different characteristics. With the distance between samples computed, clustering algorithms are needed to place them in groups. In addition to clustering, calculated correlation coefficient was done which was 0.93 when one is the maximum; therefore, this is a very powerful statistical study. The analysis performed is the Pearson correlation between actual and predicted distances based on this particular hierarchical configuration. In general, the heat map showed more positive correlations (white) and intermediate correlations (blue) between variables than negative correlations (displayed in red). Monastrell showed positive correlations in 2017 with regards to total phenols, while intermediate 
correlations were found in cellulosic glucose for 2017 and 2018. The variety MS10 had more power on color intensity, IPT and anthocyanins. By contrast, a negative correlation of MS10 in 2019, referring to the concentration of proteins, is highlighted. Convincing evidence suggests that MC80 and MC98 showed a certain relationship and positive correlation at the uronic acid level and perhaps at the level of net tannin concentration. Also highlighted was the 2018 protein concentration of MC98 along with the concentration of cellulosic glucose from MC80 in the year 2019. Results suggest that the constructed database could be applied in the characterization of Monastrell and their new varieties to systematically profile the different wines elaborated.

\section{Conclusions}

Our data have shown differences among years and varieties as regards cell wall composition in Monastrell and hybrids studied. Results obtained may suggest that differences found among the different studied varieties may be due to the genetics of each variety, largely influenced by seasonal climatic conditions. With regards to cell wall composition, Monastrell was characterized by a high quantity of glucose cellulosic and lignin could indicate a higher structural rigidity as the microscopy analysis corroborated, hindering the degradation of cell wall material during winemaking. By contrast, despite of the interannual differences, MS10 obtained the highest amount of phenolic compounds in the cell wall and MC98 the highest protein content, meaning values associated with mechanical support. Furthermore, it was interesting the high correlation found between uronic acids and anthocyanins in the new varieties. More studies are necessaries to corroborate that this is a conditioning factor of obtaining high concentrations of anthocyanins releases in the wine or not, since these grapes have a high concentration of anthocyanins in themselves. In spite of the differences found in the cell wall composition in skin grapes, analysis of phenolic composition in wines showed high significant differences between Monastrell and the new wine varieties as regards anthocyanins, color intensity, total polyphenol index, and tannins, obtaining concentrations which quadruple Monastrell wines. This could mean that the new wines from hybrids might present a very important item from the consumer's organoleptic point of view. Finally, other analysis should be carried out to reinforce and deepen our hypothesis and other authors concerning the relationship that exists between the composition of cell walls and the extraction of compounds of interest during winemaking. In addition, more in-depth studies on carbohydrate composition (rhamnose, fucose, arabinose, xylose, mannose, galactose, and glucose) could be performed which could help in the understanding the rigidity of these varieties at structure level. Yet, our studies show and reveal the great potential of these new grape varieties (Calnegre, Gebas, and Myrtia) regarding high concentration of polyphenolic compounds.

Supplementary Information The online version contains supplementary material available at https://doi.org/10.1007/s00217-022-03966-4.

Acknowledgements The authors thank the "Oenological Station of Jumilla" for their partial support of this study.

Authors' contribution Formal analysis JDM-O, MJG-B, DFP-Q, AC-P, and JCG-M, data curation JDM-O, investigation JIF-F, methodology DFP-Q, conceptualization JAB-S, writing and original draft JDM-O, funding acquisition RG-M, project administration RG-M, and resources RG-M. All authors have read and agreed to the published version of the manuscript.

Funding Open Access funding provided thanks to the CRUE-CSIC agreement with Springer Nature. This work was funded by the European Regional Development Fund ('A way of making Europe'), through FEDER 14-20-04.

\section{Declarations}

Conflict of interest Authors declare that they have no conflict of interest.

Compliance with Ethics Requirements This article does not contain any studies with human or animal subjects.

Open Access This article is licensed under a Creative Commons Attribution 4.0 International License, which permits use, sharing, adaptation, distribution and reproduction in any medium or format, as long as you give appropriate credit to the original author(s) and the source, provide a link to the Creative Commons licence, and indicate if changes were made. The images or other third party material in this article are included in the article's Creative Commons licence, unless indicated otherwise in a credit line to the material. If material is not included in the article's Creative Commons licence and your intended use is not permitted by statutory regulation or exceeds the permitted use, you will need to obtain permission directly from the copyright holder. To view a copy of this licence, visit http://creativecommons.org/licenses/by/4.0/.

\section{References}

1. Ubeda C, Hornedo-Ortega R, Cerezo AB et al (2020) Chemical hazards in grapes and wine, climate change and challenges to face. Food Chem 314:126222. https://doi.org/10.1016/j.foodchem. 2020.126222

2. Costa JM, Grant OM, Chaves MM (2010) Use of thermal imaging in viticulture: Current application and future prospects. Methodologies and results in grapevine research. Springer, Netherlands, pp 135-150

3. Wang Y, Li Y, Wang X et al (2020) The effect of climate change on the climatic regionalization of wine grapes in Northeast of China. IOP Conf Ser Earth Environ Sci. https://doi.org/10.1088/ 1755-1315/559/1/012008

4. Liang Z, Yang C, Yang J et al (2009) Inheritance of anthocyanins in berries of Vitis vinifera grapes. Euphytica 167:113-125. https:// doi.org/10.1007/s10681-008-9868-1 
5. Gómez-Plaza E, Gil-Muñoz R, Hernández-Jiménez A et al (2008) Studies on the anthocyanin profile of Vitis vinifera intraspecific hybrids (monastrell $\times$ cabernet sauvignon). Eur Food Res Technol 227:479-484. https://doi.org/10.1007/s00217-007-0744-3

6. Riquelme, F and Mártinez-Cutillas A (2018) El Libro de la Monastrell

7. Moreno-Olivares JD, Giménez-Bañón MJ, Paladines-Quezada DF et al (2020) Aromatic characterization of new white wine varieties made from monastrell grapes grown in South-Eastern Spain. Molecules. https://doi.org/10.3390/molecules25173917

8. Fernández-Fernández JI, Gil-Muñoz R, Bleda-Sánchez JA, Corredor-Cano J, Moreno-Olivares JD, Cebrián-Pérez A, MartínezBalsas D, Gómez-Martínez JC, Palencia-Sigüenza MS, CarcelénCutillas JC, Giménez-Bañón MJ, García-Pérez ML (2020) Nuevas variedades procedentes de monastrell adaptadas a clima cálido. cosechas 2016-2019. Rev Enólogos 126:68-78

9. Hernández-Hierro JM, Quijada-Morín N, Martínez-Lapuente L et al (2014) Relationship between skin cell wall composition and anthocyanin extractability of Vitis vinifera $\mathrm{L} \mathrm{cv}$ tempranillo at different grape ripeness degree. Food Chem 146:41-47. https:// doi.org/10.1016/j.foodchem.2013.09.037

10. Apolinar-Valiente R, Gómez-Plaza E, Terrier N et al (2017) The composition of cell walls from grape skin in Vitis vinifera intraspecific hybrids. J Sci Food Agric 97:4029-4035. https://doi. org/10.1002/jsfa. 8270

11. Gao Y, Zietsman AJJ, Vivier MA, Moore JP (2019) Deconstructing wine grape cell walls with enzymes during winemaking: new insights from glycan microarray technology. Molecules 24:165

12. Garrido-Bañuelos G, Buica A, Schückel J et al (2019) Investigating the relationship between cell wall polysaccharide composition and the extractability of grape phenolic compounds into shiraz wines part ii: extractability during fermentation into wines made from grapes of different ripeness levels. Food Chem 278:26-35. https://doi.org/10.1016/j.foodchem.2018.10.136

13. Paladines-Quezada DF, Moreno-Olivares JD, Fernández-Fernández JI et al (2019) Influence of methyl jasmonate and benzothiadiazole on the composition of grape skin cell walls and wines. Food Chem 277:691-697. https://doi.org/10.1016/j.foodchem. 2018.11.029

14. Dubois M, Gilles KA, Hamilton JK et al (1956) colorimetric method for determination of sugars and related substances. Anal Chem 28:350-356. https://doi.org/10.1021/ac60111a017

15. Apolinar-Valiente R, Romero-Cascales I, Gómez-Plaza E et al (2015) Cell wall compounds of red grapes skins and their grape marcs from three different winemaking techniques. Food Chem 187:89-97. https://doi.org/10.1016/j.foodchem.2015.04.042

16. Scott RW (1979) Colorimetric determination of caffeic acid in plant materials. J Assoc Off Anal Chem 62:1160-1161. https:// doi.org/10.1093/jaoac/62.5.1160

17. Bradford MM (1976) A rapid and sensitive method for the quantitation of microgram quantities of protein utilizing the principle of protein-dye binding. Anal Biochem 72:248-254. https://doi. org/10.1016/0003-2697(76)90527-3

18. Castro-López LDR, Gómez-Plaza E, Ortega-Regules A et al (2016) Role of cell wall deconstructing enzymes in the proanthocyanidin-cell wall adsorption-desorption phenomena. Food Chem 196:526-532. https://doi.org/10.1016/j.foodchem.2015.09.080

19. Theander O, Aman P (1979) Studies on dietary-fibers analysis and chemical characterization of water-soluble and water-insoluble dietary-fibers. J Agric Res 9:97-106

20. Ribéreau-Gayon P, Pontallier P, Glories Y (1983) Some interpretations of colour changes in young red wines during their conservation. J Sci Food Agric 34:505-516. https://doi.org/10.1002/jsfa. 2740340512

21. Ho P, Silva MDCM, Hogg TA (2001) Changes in colour and phenolic composition during the early stages of maturation of port in wood, stainless steel and glass. J Sci Food Agric 81:1269-1280. https://doi.org/10.1002/jsfa.938

22. Glories, Y. La couleur des vins rouges. lre partie: les équilibres des anthocyanes et des tanins. OENO One 18, 195 (1984) https:// doi.org/10.20870/oeno-one.1984.18.3.1751

23. Smith PA (2005) Precipitation of tannin with methyl cellulose allows tannin quantification in grape and wines samples. AWRI Thecnical Rev 158:3-7

24. Amrani Joutei K, Glories Y, Mercier M (1994) Localization of tannins in grape berry skins. Vitis 33(3):133-138

25. Merloni E, Camanzi L, Mulazzani L, Malorgio G (2018) Adaptive capacity to climate change in the wine industry: a Bayesian Network approach. Wine Econ Policy 7:165-177. https://doi.org/ 10.1016/j.wep.2018.11.002

26. Van Leeuwen C, Destrac-Irvine A (2017) Modified grape composition under climate change conditions requires adaptations in the vineyard. Oeno One 51:147-154. https://doi.org/10.20870/ oeno-one.2016.0.0.1647

27. Masa A, Vilanova M (2008) Flavonoid and aromatic characterisation of cv albarín blanco (Vitis vinifera L). Food Chem 107:273281. https://doi.org/10.1016/j.foodchem.2007.08.014

28. Ortega-Regules AE (2006) Antocianos, Taninos y composición de la pared celular en distintas variedades de uva. Evolución durante la maduración e implicaciones tecnológicas. University of Murcia

29. Ortega-Regules A, Ros-García JM, Bautista-Ortín AB et al (2008) Differences in morphology and composition of skin and pulp cell walls from grapes (Vitis vinifera $\mathrm{L}$ ): technological implications. Eur Food Res Technol 227:223-231. https://doi.org/10.1007/ s00217-007-0714-9

30. Nunan KJ, Sims IM, Bacic A et al (1998) Changes in cell wall composition during ripening of grape berries. Plant Physiol 118:783-792. https://doi.org/10.1104/pp.118.3.783

31. Huang XM, Huang HB, Wang HC (2005) Cell walls of loosening skin in post-veraison grape berries lose structural polysaccharides and calcium while accumulate structural proteins. Sci Hortic (Amsterdam) 104:249-263. https://doi.org/10.1016/j.scien ta.2004.09.002

32. Schnitzler JP, Madlung J, Rose A, Ulrich Seitz H (1992) Biosynthesis of p-hydroxybenzoic acid in elicitor-treated carrot cell cultures. Planta 188:594-600. https://doi.org/10.1007/BF00197054

33. Burton RA, Gidley MJ, Fincher GB (2010) Heterogeneity in the chemistry, structure and function of plant cell walls. Nat Chem Biol 6:724-732. https://doi.org/10.1038/nchembio.439

34. Boudet AM (2000) Lignins and lignification: selected issues. Plant Physiol Biochem 38:81-96. https://doi.org/10.1016/S09819428(00)00166-2

35. Nunan KJ, Sims IM, Bacic A et al (1997) Isolation and characterization of cell walls from the mesocarp of mature grape berries (Vitis vinifera). Planta 203:93-100. https://doi.org/10.1007/s0042 50050169

36. Rosli HG, Civello PM, Martínez GA (2004) Changes in cell wall composition of three Fragaria $\mathrm{x}$ ananassa cultivars with different softening rate during ripening. Plant Physiol Biochem 42:823831. https://doi.org/10.1016/j.plaphy.2004.10.002

37. Bindon KA, Smith PA, Kennedy JA (2010) Interaction between Grape-derived proanthocyanidins and cell wall material 1 effect on proanthocyanidin composition and molecular mass. J Agric Food Chem 58:2520-2528. https://doi.org/10.1021/jf9037453

38. Combe P, Ladet J (1978) Process for treatment of anthocyane extracts. United States Pat 4(083):799

39. Demir K, Celik S (2004) Determination of characteristics of grape berry skin in some table grape cultivars ( $V$ vinifera $\mathrm{L}$ ). J Agron 3:141-146. https://doi.org/10.3923/ja.2004.141.146

40. Robinson AL, Boss PK, Solomon PS et al (2014) Origins of grape and wine aroma part 1 chemical components and viticultural 
impacts. Am J Enol Vitic 65:1-24. https://doi.org/10.5344/ajev. 2013.12070

41. Gil-Muñoz R, Moreno-Olivares JD, Paladines-Quezada DF et al (2018) High anthocyanin level of grape hybrids from monastrell and their wines. Int J Hortic Agric 3:1-8. https://doi.org/10. 15226/2572-3154/3/2/00122

42. Bautista-Ortín AB, Martínez-Hernández A, Ruiz-García Y et al (2016) Anthocyanins influence tannin-cell wall interactions. Food Chem 206:239-248. https://doi.org/10.1016/j.foodchem.2016.03. 045

43. Ortega-Regules A, Romero-Cascales I, Ros-García JM et al (2006) A first approach towards the relationship between grape skin cellwall composition and anthocyanin extractability. Anal Chim Acta 563:26-32. https://doi.org/10.1016/j.aca.2005.12.024

44. Bindon KA, Kennedy JA (2011) Ripening-induced changes in grape skin proanthocyanidins modify their interaction with cell walls. J Agric Food Chem 59:2696-2707. https://doi.org/10.1021/ jf301552t

45. Quijada-Morín N, Williams P, Rivas-Gonzalo JC et al (2014) Polyphenolic, polysaccharide and oligosaccharide composition of tempranillo red wines and their relationship with the perceived astringency. Food Chem 154:44-51. https://doi.org/10.1016/j. foodchem.2013.12.101

46. Apolinar-Valiente R, Williams P, Mazerolles G et al (2014) Effect of enzyme additions on the oligosaccharide composition of monastrell red wines from four different wine-growing origins in Spain. Food Chem 156:151-159. https://doi.org/10.1016/j.foodc hem.2014.01.093

47. Ruiz-García Y, Gil-Muñoz R, López-Roca JM et al (2013) Increasing the phenolic compound content of grapes by preharvest application of abcisic acid and a combination of methyl jasmonate and benzothiadiazole. J Agric Food Chem 61:3978-3983. https:// doi.org/10.1021/jf400631m

48. Hernández-Hierro JM, Quijada-Morín N, Rivas-Gonzalo JC, Escribano-Bailón MT (2012) Influence of the physiological stage and the content of soluble solids on the anthocyanin extractability of Vitis vinifera L cv tempranillo grapes. Anal Chim Acta 732:26-32. https://doi.org/10.1016/j.aca.2011.10.056

49. Gil M, Kontoudakis N, González E et al (2012) Influence of grape maturity and maceration length on color, polyphenolic composition, and polysaccharide content of cabernet sauvignon and tempranillo Wines. J Agric Food Chem 60:7988-8001. https://doi. org/10.1021/jf302064n

Publisher's Note Springer Nature remains neutral with regard to jurisdictional claims in published maps and institutional affiliations. 